\title{
Europe To-Morrow: The Shifting Frontiers of European Civilization in the Political Thought of Richard Coudenhove-Kalergi*
}

\author{
Dina Gusejnova
}

\begin{abstract}
This paper revisits the political thought of propagandist Richard Coudenhove-Kalergi (1894-1972), revisiting his idea of a Pan-European Union in the light of past and present crises of European identity. Looking at his changing conceptions of Europe's frontiers, this article argues that Coudenhove's case offers many insights to those who seek to understand the cultural prehistory of the Cold War frontiers. His movement constitutes an example of what Michael Freeden has called a 'thin-centred ideology', and the article proceeds by contextualising Coudenhove's activities in the light of this paradigm. The article also reviews how historians' interest in his work has been shaped by present crises in European integration. The history of Pan-Europa also offers a contextualisation of such phenomena as the rise of populism and the emergence of global panmovements in the wake of political crises.
\end{abstract}

\section{Keywords}

Coudenhove-Kalergi • Pan-Europa • European identity • Early Cold War • European ideologies • European civilization

\footnotetext{
* This paper draws on material which has been previously discussed in my book, European Elites and Ideas of Empire, 19171957 (Cambridge: Cambridge University Press, 2016)

** Correspondence to: Dina Gusejnova (PhD), The University of Sheffield Western Bank, Sheffield S10 2TN United Kingdom of Great Britain and Northern Ireland. Email: d.gusejnova@sheffield.ac.uk

To cite this article: Gusejnova, D. (2018). Europe to-morrow: The shifting frontiers of European civilization in the political thought of Richard Coudenhove-Kalergi. İstanbul Üniversitesi Sosyoloji Dergisi, 38, 227-253. https://doi.org/10.26650/SJ.2018.38.2.0030 


\section{Introduction}

Richard Coudenhove-Kalergi (1894-1972), the political influencer who popularised the idea of a Pan-European Union, has been a mainstay in the historiography on European integration practically from the moment he chose to inscribe himself in its bibliography in 1922 (Coudenhove-Kalergi, 1922, 1923b). He continues to attract historians as an idiosyncratic personality, a person emblematic of his time which contained so much political promise but also radical socioeconomic uncertainty. With his Japanese mother and a father hailing from an old aristocratic family of crusaders, Coudenhove was much photographed by the emergent illustrated press. The ideology of Europe which he helped create also provided a sense of continuity between the interwar and postwar moments in European history.

In the decades since his death, Coudenhove's work has been the subject of several revivals, particularly among political historians. They took an interest in his work just as the cultural programmes of the European Union launched a number of funding streams promoting the history of European integration. The European University Institute, founded in 1976, where Coudenhove's archive is now held along with other personal and institutional papers related to the history of the EU, also began its activities in this period. The first phase of historians' engagement with his ideas can thus be dated from the mid-1980s to the 1990s, when proponents of European federalism drew on his work to polish their visions of Europe's genealogy (Lipgens, 1982). ${ }^{1}$ This was followed by a more historicist turn to Coudenhove's biography as such, enabled by the opening of archives in post-Soviet Russia (Conze, 2004; Heffernan, 1998). The Vienna files of the Paneuropean Union became a trophy in Moscow's military archives, where they had been held in secret since the Second World War. ${ }^{2}$ Finally, in the 2000s, new critical scholarship of European integration had emerged, which revisited the idea of Europe in terms of its social history and its institutional realisation (Müller, 1999, 2005; Paul, 2003). This generation of historians also took into account the impact on Europeanist political thought from the political right, as well as the place of Europe's colonial legacy in ideas of the continent's unification. ${ }^{3}$ Here again, Coudenhove's work proved indispensable, bringing to the fore his flirtations with Mussolini's fascism and his apologetic views on European colonialism. The most recent wave of historical interest in Coudenhove's work comes from scholars working on the political thought of other European regions, notably, Turkey, as well as those contrasting Coudenhove's conception of Europe with its 'others' (Barlas \& Güvenc, 2009; Gulsah Capan \& Onursal, 2007; Stråth, 2010).

1 On the research into European integration promoted around the time of the Maastricht treaty, see Shore (2000), Delanty (1995). For a great overview, see also Woolf (2003).

2 On eulogistic readings of Coudenhove-Kalergi, see Burgard (2000), Gehler (2002), Ziegerhofer-Prettenthaler (2004). The first biography was by a Japanese scholar, Morinosuke Kajima (1971).

3 On critical scholarship in this vein, see Conze (2005), Hansen and Jonsson (2014), Botz-Bornstein (2007), and Richard (2014). 
Why return to Coudenhove's political thought once again? Seeing European identity through Coudenhove's eyes enables us to analyse from a historical and comparative perspective how times of political disorientation can be conducive to the emergence of cross-party ideological movements. His ideas are also of relevance to those who are interested in historicising recent political crises. In this paper, I hope to shed light on Coudenhove's project as an ideology which emerged in response to European disintegration, rather than looking at it as a milestone in the teleology of European integration. His ideas made up what the political philosopher Michael Freeden has called a 'thin-centred ideology': a formation prompted by an acute perception of a present crisis - in his case, the collapse of the old continental European empires which, however, was not matched by a commitment to a comprehensive solution to this crisis (see Freeden, 1998). Coudenhove's views of Europe's political frontiers, which responded to a succession of dramatic political changes in his own lifetime, can enable historians to better understand the relationship between individual agency and political ideology.

The historiography on Coudenhove-Kalergi has itself become an area of political thought within which changing ideas about European identity have been expressed. But while previous engagements with his work - particularly in the 'end of ideology' atmosphere at the end of the Cold War - have linked him to the history of European integration, the most recent chill in political relations in Europe and other, more global, political crises, open up a different picture. Today, the relevance of his ideas comes from the insights which might be gleaned from his work as a political influencer in a postimperial world. Today's political analysts are constantly re-examining the categories within which to understand how modern-day Russia and Turkey grapple with their former imperial legacies, new national and secessionist movements, and the challenges of economic globalisation. ${ }^{4}$ Understanding the evolution of Coudenhove's ideas can arguably facilitate a more historically granular understanding of postimperial anxiety about Europe's frontiers.

Coudenhove's mode of working, lobbying across ideological frontiers and in the communities of bankers and entrepreneurs with which he was familiar, has a very contemporary resonance for a range of reasons. He not only sought out a range of creative mechanisms for maximising economic as well as cultural forms of influence. By turning his journal into a platform where his contemporaries' views of Europe's past and future could be shared through polls and questionnaires, he was also singularly receptive to the contemporary phenomena of his time such as the rise of electorate polling and the use of referenda in determining the outcomes

4 On the current crisis of European frontiers, see, for instance, Dov Bachmann and Gunneriusson (2015), Shevtsova (2015), and, on the Turkish case, Bacik (2011). 
of postwar geopolitical conflicts. ${ }^{5}$ Coudenhove was not only an opinion trendsetter. His magazine fostered the emergence of Europeanist thought by collecting critical surveys and acting as a soundbox for ideas of Europe. ${ }^{6}$ Together with other initiatives promoting broader, supra-political causes, Coudenhove's work belonged to the category of 'non-governmental organizations' (Boli \& Thomas, 1999). ${ }^{7}$ Yet the history of Coudenhove's 'thin-centred' ideology also shows the limits of his popular appeal.

\section{Democracy and Moderate Nationalism: Paneuropa in the Interwar Period}

Coudenhove was only twenty-eight when he launched his proposal for a PanEuropean union; his last work on the subject, Europe as a World Power, was published when he was nearly eighty (Coudenhove-Kalergi, 1971). The actual demands of his programme, and particularly, Coudenhove's attitude towards political ideologies and forms of government, changed multiple times throughout this period. The initial aim of the Paneuropean Manifesto was the reconciliation of nations along pacifist and democratic ideals after the disasters of the First World War. In fact, leading pacifists had claimed that Coudenhove had stolen some of their ideas from them (Wehberg, 1927, pp. 102-103). Coudenhove's work at this time bore the influence of masonic ideas, a result of his membership of the masonic lodge Humanitas until he resigned in 1926. Coudenhove emphasised the emotional, economic and political bonds which tie Europeans to each other, and depicted his ideal Europe as a federation of national democracies (Coudenhove-Kalergi, 1924c). Not all European states were also panEuropean: as a political concept, Coudenhove's Europe comprised all 'democratic states of continental Europe including Iceland'. By the same logic, the European part of Turkey still belonged politically to Asia. Likewise, Russia under Bolshevik influence was increasingly moving away from Europe politically (CoudenhoveKalergi, 1924c, p. 36). At different moments, he defined Europe principally in terms of its opposition to different cultural or political entities. This included continents - Asia and America; political federations - Britain and the Commonwealth, and the Soviet Union; cultural communities, such as Islam and Muslim civilization; and new states such as Turkey.

Scholars' assessments of Coudenhove's political orientation have ranged from liberal internationalism to Christian conservatism (Conze, 2004; Heffernan, 1998). ${ }^{8}$

5 On referenda as a feature of the political landscape after the First World War, see Conrad (2015) and Qvortrup (2015).

6 See especially the discussion of opinion polls in Majer and Höhne (2014).

7 On the intellectual context of aristocratic German-speaking authors writing on Europe's future, see Gusejnova (2016).

8 On neo-aristocratic thought, see also Breuer $(1999 ; 2001)$. 
His values were conservative but he considered his thought to be in a tradition of utopian writing inviting social and political reform, which meant that he included elements of socialist welfare in his programme, accompanied by an economic policy based on German national liberal traditions advocated by such thinkers as Friedrich List. Dictatorship and monarchy were negative terms for him, leadership, democracy and aristocracy positive terms. He described his own views as 'neoaristocratic' and argued that humanity needed spiritual and ethical leaders, and that a community of such leaders who wanted the best for humanity was worth aspiring to.

In addition to pacifism and democracy, Coudenhove had specific ideas about the economic dimension of European unification. He acknowledged the existence of national interests, but he was also keen to explore what might be meant by a common, pan-European interest. Because the League of Nations was a global organisation, it could not be trusted with safeguarding the interests of Europeans, he thought. Mustering economic strength in a global intercontinental competition required rethinking the way resources were used, including the colonial question. Coudenhove emphasised that without colonies, Europe had 5 million square miles and 300 million inhabitants. With colonies, it had a much larger territory of 25 million square miles but without an equally large population - a total of 348 million. The untapped resource of Europe's colonies was therefore a highly promising foundation for cementing Europe's future as a world power. Two further sectors of importance were coal and steel, and banking. Towards the end of the 1920s, Coudenhove developed more precise ideas about the organisation of the internal economy in facilitating European integration, advocating a kind of corporatism which was also then developed on the political right by politicians such as Dollfuss and Mussolini. This was matched by his practical attempts to influence policy by drawing on connections in the banking and industrial sectors from Germany, Czechoslovakia, France, and Austria. His list of supporters included the Czech entrepreneur (and owner of the famous shoe production chain), Tomas Bata; the German industrialists Paul Silverberg, Carl Siemens, Adam Opel, Edmund Stinnes, Richard Gütermann, and Hermann Bücher (of the AEG); Carl Duisberg (of the Bayer corporation); the bankers Herbert Gutmann, Arthur Gwinner, Hans Fürstenberg, and Carl Melchior (a friend of Rathenau's); the Dutch industrialist N.V. Philips; and the Austrian Otto Böhler; as well as the German Danat, Mendelssohn, and Warburg banks. ${ }^{9}$

There was thus a combination of theoretical and pragmatic elements in his thinking about European identity. Keeping these together required political organisation. The dangers for Europe lay in discord based on competing national interests, which

9 See Coudenhove to Louis Loucheur, 3 February 1928, 3 May 1928, telegram of 10 December 1928, and 19 January 1929, in Stanford, Hoover Institution Archives (HA), Loucheur Papers. 
ran the danger of developing into an economy of small states, or Kleinstaaterei. ${ }^{10}$ To overcome these moments of discord, Coudenhove proposed using America as an example, which used its hegemony to foster Pan-American connections without the need to form one American superstate. The Pan-American conferences, which started in 1881 and took place in a different American nation each time, served Coudenhove as an inspiration for launching his own series of conferences and a journal accompanying the movement.

To say that Coudenhove emphasised democracy as a necessary feature of Europe's future requires qualification. The democratic element in his plan was understood not as an expression of the cumulative interests of individual citizens, but rather, of the group interests of nations. Coudenhove's ideal model comprised two houses of parliament whereby one chamber - the larger one - represented nations or peoples, and another chamber represented states. This was rather similar to the way democratic elements had been introduced to Austro-Hungarian politics after the compromises between the House of Austria and the various nations of the empire. ${ }^{11}$ The main source of influence in this respect was the work of Aurel Popovici (1863-1917), an Austrian political thinker of Romanian background who, in 1906, had published a proposal for the United States of Greater Austria in Leipzig (Popovici, 1906, 1918). Popovici wanted to give the different ethnocultural components of the Austro-Hungarian empire greater national autonomy in matters of culture and education within the empire; in exchange, they would remain bound to Greater Austria - as opposed to Hungary - by means of a federal union. This union would comprise fifteen quasi-independent units defined by language. Each of the fifteen states in the union would receive votes in the legislative chamber of the imperial government. In addition to his desire to reform the Habsburg empire, Popovici's theory was influenced by Swiss federalism, particularly, the ideas of the legal theorist Johann Caspar Bluntschli, and the constitutional model of the United States. ${ }^{12}$ He stated his explicit motivation in writing the work, aside from being a call to reject Magyarization, was to ensure the 'future of the Habsburg empire'. ${ }^{13}$ However, what distinguishes his proposal from Coudenhove's is Popovici's outspoken anti-Semitism and the attack on what he called the 'Jewish liberal press' which he associated with such mainstream Viennese newspapers such as Neue Freie Presse.

10 Coudenhove to Louis Loucheur, 1928, p. 39.

11 On democratic politics in the Habsburg empire, see Judson (2016).

12 He cites extensively from Bluntschli (1886), as well as idem, Bluntschli (1881). See also Auerbach (1898), Gumplowicz (1879), Chamberlain (1899, vol. I, p. 263; C. Darwin, Animals and Plants under Domestication, ch. xV and xix apud Chamberlain, here p. 8 footnote 5). The rest Spencer (1904), recommends to the Japanese to abstain from racial mixture. 89. Gobineau and le Bon (1894). Other citations are of Disraeli's novel Coningsby, to Carlyle and Macaulay, and to J.C.L. Sismondi (1839).

13 Popovici (1906), dedication to the reader. 
Aside from these texts of Habsburg policy, Coudenhove also relied on a number of canonical works of political thought as a source of inspiration. Nietzsche's Will to Power manuscripts (Coudenhove-Kalergi, 1930, pp. 95-101) were part of a reading list Coudenhove-Kalergi set for future Paneuropeans, which also included Napoleon's Political Testament,$^{14}$ as well as a dozen or so other works by Dante, Comenius, Grotius, Kant, and Mazzini (see, for instance, Saint-Pierre, 1714; Fénelon, 1720). Drawing on Giuseppe Mazzini's Europe: Its Conditions and Prospects, Coudenhove picked up on the traditions of the Young Europe movement, which bridged nationalism and cosmopolitanism (Bayly \& Biagini 2008). The combination of the two principles was what motivated him to include the Bohemian humanist Comenius. Coudenhove's journal, Paneuropa, devoted a great deal of attention to publishing seminal texts in which European identity was discussed. At the opening of the first Paneuropean Congress in 1924, Coudenhove's wife Ida Roland recited Victor Hugo's speech on European unification 'in the service of propaganda for the Paneuropean idea' ${ }^{15}$ Further congresses were held in Berlin in 1930, in Basel in 1932, in Vienna again in 1935, and finally, in exile, in New York in 1943.

Another element in Coudenhove's political thought was his conviction that the distinction between key forms of government available to modern civilizations had itself been worked through European history, during which republics had defeated monarchies in the long run. By contrast to the early nineteenth century, when the Holy Alliance of European monarchies could be equally used to express European solidarity as Mazzini's republicanism, by the twentieth century, Coudenhove argued, the principle of republicanism associated with Mazzini had defeated the principle of monarchical internationalism associated with Metternich. 'The World War brought about the decision about: Mazzini attained victory over Metternich, the thrones of Central and Eastern Europe tumbled, the suppressed nations obtained their freedom, Europe became democratic, and this broke the path for the creation of a new, sixth Europe.' (Coudenhove-Kalergi, 1924b). As Coudenhove envisaged it, if the Europeans followed his plan, they would eschew the vexed question of sovereignty by becoming a movement which would be a supra-party lobbying group internally, and a federative international association externally (Coudenhove-Kalergi, 1931b). Its foundation was to be economic integration and the joint exploitation of Europe's African colonies - with the exception of the Commonwealth, which, in the early drafts of the programme, would remain the prerogative of Britain.

On account of its dominions, Britain was unable to commit to another union of comparable size, as Coudenhove argued, and had to be excluded for reasons of a

14 Reprinted in Paneuropa (1929, pp. 18-22).

15 Victor Hugo, 'United States of Europe', speech held at the Paris Peace Congress of 1849. Ida Roland recited it at the Paneuropa Congress in Berlin in 1930. Mentioned in 'Wiederauftreten Ida Rolands in Wien', Neue Freie Presse, 7 June 1933. 
global balance of power; while Pan-Europe was to be modelled after what Coudenhove called 'Pan-America' both in its federal structure and its attitude to colonial resource. Coudenhove's demands were, first, a revision of the Versailles agreement, especially with regard to the question of the German (and Austrian) war guilt; a 'perpetual' peace between all the European states; doing away with any customs and other economic borders and bringing about a unified currency; a joint army and fleet; a European 'limes' on its East border and erosion of all inner European borders; a true guarantee of minority rights and the introduction of punishment for any propaganda of hate in the press; a Europeanization of education at schools; and a pan-European constitution.

Paneuropa, this non-partisan, partly technocratic, partly utopian federation of interests represented by national chambers in a republican and democratic model of government, required sentimental bonds as well as practical projects to make the project viable. Coudenhove found the sentimental element in the cultivation of admiration of great historical personalities who acted as an inspiration for more than one European nation, and even beyond: Kant, Nietzsche, Mazzini, Napoleon, Dante, and others. ${ }^{16}$ The cultivation of character - a mixture between the ideal of the old nobility and the dream of a new mixed-race, educated type of person - was a key element of the plan to make Europe come together despite divergent national and regional interests, and in the absence of monarchies and dynastic loyalties. The leader ['Führer'] was to replace the ruler [,Herrscher'] as a political type, and this would enable the idea marriage between romantic utopianism and pragmatic realism (Coudenhove-Kalergi, 1925a).

Technological solutions were another model for activity. Among Coudenhove's least successful attempts to influence government members was his attempt at a solution of the Polish corridor problem, which, being an outcome of the Versailles settlement, separated two parts of Prussia from each other. Coudenhove sent letters of consultation both to the German and the Polish governments and also published information on it in his Paneuropa publishing house. His plan was based on the recognition that European peace was only possible if Germany was at peace both with France and with Poland. Realising that Poland found it unacceptable to renounce its only access to its main port, Gdynia, whilst Germany could not accept the separation of East Prussia from its territory, Coudenhove argued that the area around the corridor had to be marked by a line under German sovereignty on which would pass a 'double railway line and an automobile route which would connect Danzig viz. East Prussia with the rest of the Reich territory. ${ }^{17}$ Coudenhove emphasised that where this line could not be maintained without infringing on Polish transportation within the corridor,

\footnotetext{
16 Ignaz Seipel opening first Paneuropa Congress of 1926, Fond 554.7.470.343-416, Coudenhove-Kalergi papers, RGVA, Moscow.

17 Coudenhove-Kalergi to Reichskanzler, in BA, R 43 I/125, pp. 364-377.
} 
'it will have to pass subterraneously through a tunnel. A commission consisting of a representative of the German and the Polish government coordinates all the conflicts resulting from this technical-juridical construction', Coudenhove suggested. His plan included the construction of a Polish canal for its commercial traffic involving the Swiss engineer Jules Jaeger and his son Charles, who had already excelled with a construction of bridges and dams in Switzerland. 'Now they have spontaneously decided to provide a plan for the technical solution of the question of the Polish corridor' which, Coudenhove argued, would 'turn out cheaper than half a battleship.' Coudenhove summed up his proposal as an attempt 'to find extraordinary solutions for extraordinary problems', one that the spirit of the twentieth century demanded. ${ }^{18}$ In March 1931, Coudenhove wrote from Paris about his encounter with Polish Prime Minister August Zaleski, who, according to Coudenhove, expressed his willingness to meet the German High Chancellor in Geneva or elsewhere in order to discuss the matter with him in person. ${ }^{19}$ Like Coudenhove, Beneš and Masaryk, Zaleski joined the freemasons during World War I, when he worked as a lecturer in Polish language and literature in London. He was foreign minister of Poland between 1926 and 1932. State secretary von Bülow distanced himself from Coudenhove's involvement in government decisions, writing in internal chancery communications that 'Count Coudenhove-Kalergie's [sic] conversations on foreign policy, which he speaks about in his letter to the Reich chancellor, are entirely unwelcome to German politics. [...] We have always held that palliative little means to alleviate certain particularly evident grievances on the Eastern frontier do not help us.' Bülow suggested responding to Coudenhove with an abrupt confirmation of receipt: 'Such a way of putting it would also have the benefit of preventing the Count from seeking to muddle through using special connections'. In response to Coudenhove's attached printed proposal for the Polish corridor, one civil servant (Oberregierungsrat Planck) commented in internal correspondence on 16 August 1931: 'Count Coudenhove-Kalergi's proposal continues to be unwelcome.' The incident nonetheless demonstrates the combination of idealism and practical intervention which characterized Coudenhove's ideas.

Importantly, European civilization for Coudenhove was as much an accomplishment of earlier ages, as it was a task for the future. Increasingly, his thinking about Europe shifted from territorial to temporal dimensions. Initially, the Paneuropean programme was accompanied by a map which showed Europe as one territory without borders, with the exception of Turkey, which was marked with a question mark. The Paneuropa programme demanded a 'systematic exploration of the European economic colony of West Africa (French Africa, Libya, the

18 Coudenhove-Kalergi to the Reichskanzler. Paris, 27 March 1931, in BA R 43 I/125, pp. 265-266. On the handling of the Danzig corridor issue, see also section on 'Die Kabinette Brüning I u. II' (Erdman \& Koops, 1982). The 'corridor inside a corridor' had also been suggested by the French diplomat Wladimir d'Ormesson.

19 Coudenhove-Kalergi to Reichskanzler, in BA, R 43 I/125, pp. 364-377. 
Congo, Angola) as a European resource' (Coudenhove-Kalergi, 1924a). By 1934, Coudenhove emphasised the significance of European identity as a community of values which was to some extent independent on the precise nature of its territory. It was constituted by ideas, including 'Greek philosophy, Roman law, Christian religion, the lifestyle of a true gentleman and the declaration of human rights' (Coudenhove-Kalergi, 1925b). The question mark on Turkey was due to some of its territorial belonging to Europe 'despite' its Muslim heritage. By the mid-1930s, he overcame this in favour of a culturally transcendent conception of modernity, which, in the Turkish case, he associated with the impact of Mustafa Kemal on his society and its relations with Ottoman successor states such as Greece.

Coudenhove himself was one of several intellectuals of aristocratic background who made his provenance part of his campaign, alongside figures such as Karl Hubertus zu Löwenstein, Prince Karl Anton Rohan and Count Hermann Keyserling (Reytier, 2004; Gusejnova, 2013). ${ }^{20}$ In his view, the European aristocracy had not only shown the negative effects of this isolationist practice, but also ,kept the bourgeoisie away from itself". It was a paradox that even the democratic states of Europe still entrusted their affairs to the descendants of aristocrats. 'For many generations, the European blood nobility has lived in a political atmosphere which barred the bourgeoisie from entry into politics. [...] Politics is an art, not a science. [...] In the sciences, the bourgeoisie excels over the aristocracy in terms of talent: in politics, the relationship is reversed. This is why Europe's democracies also frequently entrust their government to descendants of high nobility, for it is in the reason of state to make the inherited mass of political talent accumulated by the nobility over the years available to all.' (Coudenhove, 1925a, p. 47). Despite this effectively apologetic attitude towards social inequality in European history, Coudenhove also affirmed the importance of racial and cultural mixing. The ideal European was multiracial, a 'planetary type' - rather like the high aristocracy in its ethos, but the opposite of its principle of inbreeding.

The creation of a future European civilization also required consciousness of clear boundaries between Paneuropa and other world regions, in particular, empires and states with new imperial ambitions. There were three states with a significant presence in Europe who could not be represented in his model, at least as first articulated in the 1920s -- Russia, Turkey, and Britain. These exceptional cases of European (or partially European) states which were to be excluded from a future European Union stood alongside the 'natural' others of Asia and Pan-America. What distinguished all three cases was their difficult relationship to their own empires: the Soviet Union had succeeded the Russian empire in a way in which the Commonwealth was in the

20 See also Prince Karl Anton Rohan's journal Europäische Revue, which was first published in 1925 (Vienna and Berlin, 1925-1943). 
process of replacing the old structures of empire in Britain. Modern Turkey was, similarly to the Soviet Union, a modern state whose identity was built on rejecting its Ottoman past and yet whose hegemony drew on its legacies. Coudenhove's Paneurope movement was to have its base in Vienna. On the surface, Austria was, of course, also a postimperial successor state, but one with no claim to hegemony whatsoever. It was this diminished status in the modern world - together with the consciousness of its historic past --- which gave Vienna the capacity to lead a new movement whose aim was to regenerate a new European patriotism.

The symbol of the Paneuropa movement, a red cross against the yellow sun of Hellenic Greece, reveals the intellectual legacies to which Coudenhove imagined himself heir: what could be called the Christian tradition of geopolitical integration, historically framed from the Crusades, to the European unification models of Abbé St. Pierre, and to the Christian socialism of the late nineteenth and early twentieth century. Within this tradition, freemasonry was an important sub-group; and indeed, Coudenhove himself regarded Enlightenment projects which themselves criticised Christian traditions as falling within the Christian trajectory. The intellectual background of masonic eclecticism merged neo-Hellenic ideals with Kantian rationalism as well as the German ideal of Bildung, the ideal of culture and education, together with more recent calls for German cultural unity and an imperial discourse. These strands of thought were invoked at Coudenhove's first international Paneuropa congress.

This genealogy of European unity as Coudenhove presented it was thus composed of several sometimes contradictory traditions: ideas of a Christian Empire and monarchy; ideas of national liberation which were based on resistance to large dynasties; ideas of a balance of power and contrary ideas of economic integration by its critics; and the emphasis on charismatic political leadership and technology as features of modern political systems, against the neo-medievalism of some of his other beliefs. Coudenhove's Christian-Hellenic baggage did not prevent him from speaking of Vienna as 'the Mecca of the Paneuropean Union' (Coudenhove-Kalergi, 1949). In establishing this account of Paneuropa's pedigree, Coudenhove not only marketed the noble ancestry of his own idea, but also sought to borrow authorities from other political movements. He reclaimed Kant and Grotius from Wilson and the liberal internationalists; Mazzini from the European nationalists such as Masaryk; and Victor Hugo from the social democrats. In drawing on a variety of authors, Coudenhove emphasised the inherently cosmopolitan background of the European ideal. The masonic eclecticism of his ideal of Europe was, interestingly, strongly reminiscent of the City of the Sun narrative by Tommaso de Campanella, whose depiction of this ideal city included references to Egyptian and Roman polytheism just as to Christianity, Islam, and fiction. 
Britain, Coudenhove argued, had to be excluded for reasons of a global balance of power, while Paneuropa was to be modelled after what Coudenhove called 'Pan-America' both in its federal structure and its attitude to colonial resource. Coudenhove's called for a revision of the Versailles agreement, especially with regard to the question of German (and Austrian) war guilt; a perpetual peace between all the European states; doing away with any customs and other economic borders and bringing about a unified currency; a joint army and fleet; a European limes on its eastern border and erosion of all inner European borders; a true guarantee of minority rights and the introduction of punishment for any propaganda of hate in the press; a Europeanization of education at schools; and a Paneuropean constitution (Coudenhove-Kalergi, 1922, pp. 3-4). Paneuropa was thus based on an essentialist perspective on European identity, and yet demanded policies of identity construction through education and infrastructure. ${ }^{21}$

With its combination of idealism and pragmatism, Coudenhove's Pan-Europe bore the mark of a postimperial project which sought to preserve whatever good elements could be rescued from the Habsburg empire He saw danger in any form of extreme nationalism, which had long threatened and in the end fatally weakened the Habsburgs. The Austrian government had offered Coudenhove offices in the Vienna Hofburg, which allowed the movement to be registered under the illustrious address of 'Paneuropa, Hofburg, Wien' until the annexation of Austria by Germany in 1938 (Coudenhove-Kalergi, 1966a pp. 223-224). This expressed symbolically how significant the Habsburg legacy and its prestige were for the movement's operations, but also its limits in the face of new, more aggressive movements for Greater Germany.

A key element to Coudenhove's political thought was his view of Europe as a world power with a special claim to the concept of civilization. Despite some unique characteristics, Coudenhove's work can be best understood when considered in the broader intellectual context of works on the idea of Europe, as diverse as Oswald Spengler's Decline of the West (1918-23) or Hermann Keyserling's Das Spektrum Europas (1928), which were themselves a response to questions raised by a previous generation of intellectuals, notably, Nietzsche. ${ }^{22}$ As Coudenhove himself put it, in the interwar period, 'the only [true] Europeans were the writers', mentioning authors like Heinrich Mann or Maximilian Harden (Coudenhove-Kalergi, 1966a, p. 121). Writers

21 First formulated in 1922, it reached a wider English-speaking audience in the 1930s (see CoudenhoveKalergi, 1931c).

22 Nietzsche, 2002; esp. Preface (pp. 1-4), part 5 'On the natural history of morals' (pp. 75-92), part 8 'Peoples and fatherlands' (pp. 131-150) and part 9 'What is noble?' (pp. 151-177). For Coudenhove's contemporaries Politis (1946, pp. 129-131); Brockhausen (1924); la Rochelle (1931); Delaisi (1929). In his 1929 book Les Deux Europes, Delaisi described the division of Europe in two halves, 'Europe A' and 'Europe B'. The former consisted of the wealthy and industrialised countries in Western Europe, the latter of the newly founded states of Eastern Europe with a mainly agricultural economy (Febvre, 1999; see also Dawson, 1932, 1934, 1941, 1944-57; Fisher, 1938). 
of international fame, like the Bengali poet Rabindranath Tagore, the English novelist H.G.Wells, the French novelists André Malraux and Romain Rolland, who enjoyed the status of intellectual celebrities at the time.

Such authors published in multiple journals, their texts appeared in different forms and translations in a diversity of journals discussing geographical and cultural identity. Some of the Europeanist authors, like Coudenhove himself, but also his great rival, Prince Karl Anton Rohan, ran their own journals. Rohan's Europäische Revue attracted a wide range of authors, from German conservative revolutionaries and associated authors, such as Carl Schmitt, Max Scheler, but also more moderate conservatives like Hugo von Hofmannsthal, to French radical socialists and Italian syndicalists; among its international authors were Paul Painlevé, the humanitarian, Paul Langevin, the radical socialist, as well as Italian fascists like the corporatist Giuseppe Bottai (Bock, 1994; Müller, 2005). In parallel to Coudenhove's masonic elements, this journal had a Christian theme running through its issues, positing Christianity as a source of a shared European identity, and operated with the term 'Mitteleuropa'. Apart from the nature of the desired political order in Europe, which was the journal's main focus, its authors also wrote extensively on America and international relations beyond Europe (Bühler, 1929; Halfeld, 1928; Lanux, 1929; Seed, 1928).

Intellectuals like Coudenhove were reacting to changes which affected the character of public discussion of Europe after the end of the First World War. Intellectuals became more politically engaged, and as a result journals which had been apolitical before began to address more openly political debates; in addition, because of the decline of salon culture, new journals and publishing houses promoting 'worldviews' rather than specific party political programmes became widespread. This new interest in geopolitcs and the revived interest in exoticist critiques of Europe brought about a new wave of journals theorising European identity (see especially Schmitt, 1929). Journals can thus be used to trace the changing political character of such social 'configurations' of intellectuals as expressionism. Like other contemporaries, Coudenhove founded a dedicated journal and a publishing house to vent his own ideas. In the course of the 1930s, when he developed plans for a European Academy at Prague,

Coudenhove-Kalergi invited the German geographer Karl Haushofer for a position as a Fellow of this academy, and furthered contacts with other theorists of geopolitics as well. ${ }^{23}$ In Britain in this period, thinking about Europe's future had its place at Chatham House, a think tank which was founded in the wake of the First World war

23 On the German geopolitical tradition that emerged in the wake of World War I, see Kjellén (1917; 1930); see also Bassin (2004), and Heffernan (1998). 
and had its own outlet, the Journal of International Affairs. ${ }^{24}$ Coudenhove addressed members of the house both in person and through correspondence with some of its members, which included Arnold Toynbee and Leo Amery, both of whom had a past working for British intelligence in the Balkans.

If we look at the variety of authors publishing in journals discussing European identity and the authors whose books were reviewed there, the diversity of the political spectrum associated with Europeanism becomes amply apparent. It is difficult to say what united authors contributing either to Europeanist journals or to journals in related fields discussed above. Such authors ranged from socialists like Emile Vandervelde or Hendrik de Man, to conservatives like Hugo von Hofmannsthal, to corporatists and chauvinists like Othmar Spann. They problematised German, Slavic and Jewish identities. Authors of fiction publishing in these journals included utopianists, orientalists, and 'critical realists'. Political and religious movements represented ranged from Catholicism to Judaism, from feminism to male chauvinism. Even though some of the journals developed in more defined directions in the course of their existence - thus the Europäische Revue became known for its 'conservative revolutionary' stance, for instance - no label can adequately characterise these journals because most of their authors contributed to several journals simultaneously. They wanted to transcend the ideologies of existing parties - for they united writers of different political beliefs; and yet produce an alternative worldview of European identity which could serve political ends.

\section{Learning from the Balkans, and Pragmatism against Totalitarianism}

By the mid-1930s, Coudenhove changed his mind about the future of Europe. First, he now actively pursued both Turkey and Britain as members of his movement (Coudenhove-Kalergi, 1931a, pp.13-14). This change echoed that of some of his key rivals, such as Prince Karl Anton Rohan, whose journal, the Europäische Revue, also ran a special issue concerning Turkey with Turkish contributors (more on this, see Greiner, 2015). Like Coudenhove, Rohan at this time welcomed discussion of corporatist forms of government. His goal for a European order can be described along the lines of a state which can but does not have to comprise elements of democracy (Fourgeaud, 1929). In the 1930s, Coudenhove travelled to Constantinople and London, with speaking engagements in such places as Chatham House. At this time, he began to focus on analysing and praising more modest examples of success in different European regions. In particular, he praised the way the Balkan states had

24 On the British reception of Paneuropa, Quincy Wright, review of Pan-Europe by Richard N. CoudenhoveKalergi, in Political Science Quarterly (1927); Arthur Deerin Call, review of Pan-Europe by Richard N. Coudenhove-Kalergi, in The American Journal of International Law (1927). See also Amery (1930), Toynbee (1931), and Parmar (2002). See also Ashworth (2002), Rich (2002), Pugh (2002), and Porter (2002). 
achieved reconciliation by such mechanisms as the population exchange between Greece and Turkey led by Eleftherios Venizelos and Mustafa Kemal, and the founding of the Balkan Entente of 1934 (Coudenhove-Kalergi, 1937a, 122). He also began to explore alternatives to democracy as a means of European unification. Coudenhove believed that 'Nietzsche's Will to Power is where the foundational thoughts of fascist and Paneuropean politics stand side by side'. Youthfulness was a common theme with the new political movements like fascism, which Coudenhove distinguished sharply from National Socialism due to its comparative lack of emphasis on the racial question (Coudenhove-Kalergi, 1923a, p. 1).

What had caused the changes in his views about Europe's frontiers at key junctures? There were a number of reasons. The economic crisis put an end to the optimism regarding technocratic and financial means of European unification. This encouraged Coudenhove to devote more attention to the question of economic cooperation across ideological and national fault lines. ${ }^{25}$ Coincidentally, some of the political champions of his ideas in Europe, such as Gustav Stresemann and Aristide Briand, had died at the same time. Then came the rise to power of the Nazis and the development of its plans for European domination. As a result of all this, Coudenhove's plans not only became more reactive in character, but also changed focus. He recognised that his contemporaries, too, were increasingly uncertain about the relationship between Europe's geographical borders and its political frontiers, and even started a survey in his journal to capture this uncertainty. Three answers were possible: the Urals, the Sea of Marmara, and an open answer. Of 42 respondents he recorded, 27 chose the Urals and 18 chose the Russian-Bulgarian border in the Sea of Marmara (CoudenhoveKalergi, 1935, 1938). To verify the foundations of people's opinions, Coudenhove included another survey in a later issue, which asked whether the Russian revolution of 1917 or subsequent central European revolutions in 1918 had made a difference to the way people conceptualised the border (Ziegerhofer-Prettenthaler, 2004, p. 338).

Coudenhove's own shift from thinking about Europe in terms of frontiers to thinking about it in terms of integrated regions deserves closer analysis. According to Coudenhove's own memories, the Greek prime minister Eleftherios Venizelos had urged him to consider Turkey as a potential member of Paneuropa, having himself been at the forefront of Greco-Turkish reconciliation. 'I recollect how the great Greek statesman Venizelos explained to me his decision to go to Ankara to offer Kemal Ataturk a pact of close cooperation and friendship, after the horrors and atrocities of the last war between Greeks and Turks and after six centuries of blood and hate. Both men were big enough to start a new page of history.' (Barlas \& Güven, 2009). The means of achieving this was population exchange, confirmed in the course of the Lausanne Treaty of 1923, which resulted in greater ethnic homogeneity of both 
Turkey and Greece - an aspect which should have alerted Coudenhove with his advocacy for cultural mixing, and yet something he was willing to overlook in the interests of peace. Over 1.5 million people from both nations were affected by the exchange. ${ }^{26}$ The Greek international lawyer Nicholas Politis, who in 1924 became the Greek Ambassador in Paris, was a long-standing member of the Paneuropean movement. He was Coudenhove's connection to the League of Nations, and initiated a study group on European unification there at the time when Coudenhove and Briand worked together (Papadaki, 2012, p. 231). At this time, and until 1930, the League of Nations had also overseen the Greco-Turkish resettlement policy.

As a fellow Cretan (the Kalergis family was an old Cretan patrician family), Coudenhove felt an affinity with and a great sense of trust in Venizelos. Coudenhove also opened up his journal to publications by leading Greek politicians such as the banker and foreign minister in Venizelos' government, Demetrios Maximos (Demetrios, 1934, p. 111-112). In 1943, when Coudenhove was mobilising for the idea of European federalism from New York, he approached Nellos Camellopoulos, a former member of the Greek Parliament, for support. While Turkish intellectuals were far less represented in Coudenhove's circle and his bibliography, he did invite a contribution on the economy in modern Turkey by Bedri Tahir in 1934, following a visit to Turkey during which Coudenhove tried to mobilise an international alliance against Nazism (Bedri, 1934, pp. 115-117). ${ }^{27}$ By 1943, Coudenhove thought: ' The most important step toward such a new understanding between Europe and the Near East has been accomplished by Modern Turkey, that recently under its leader Kemal Ataturk, embraced without any European pressure all the vital elements of Western civilization. This Turkish Revolution is paving the way for a complete reconciliation between Europe and the Near East' ${ }^{28}$ In the absence of history, modernity was a ticket to European civilization.

His encouragement for Britain to join the movement came in 1939 (CoudenhoveKalergi 1939). ${ }^{29}$ When he had first spoken at Chatham House eight years prior to that, Coudenhove met with a lukewarm reception when he entered into dialogue not only with metropolitan British internationalists and members of the government, but also with intellectuals involved in shaping Britain's affairs in the Commonwealth, notably the Muslim representative of the Indian Congress, Yusuf Ali, who had also served on the Indian delegation to the League of Nations in 1928 (CoudenhoveKalergi, 1931c). Ali thought that Coudenhove's insistence to exclude Britain as well as Russia made Paneuropa meaningless. 'If Great Britain and the British Empire

26 For details on the treaty, see Marrus (1985, p. 103).

27 On Coudenhove's visit, see Barlas and Güven (2009, p. 438).

28 'European Union is Favored. Count Coudenhove-Kalergi Replies to Some Objections to His Plan', New York Times, 22 Dec 942.

29 Contrast with his earlier discussion of the subject Coudenhove-Kalergi (1931c). 
were excluded and if Russia were excluded, a great deal of the attraction and working chances of the idea would be removed.' (Coudenhove-Kalergi, 1931c, p. 647). Ali added, however, that even if the plan for a federation did work, it would not be sustainable because there was no such a thing as a common European interest. Europe had conflicting regional interests, not to speak of colonial conflicts in Africa and the Indian Subcontinent. He highlighted especially the likely resistance of the European powers towards joint colonial exploitation, which they would interpret as a truncation. On top of that, he drew attention to the appeal of Russian influence and communist ideals for countries like India, due to the existing discontents there. Finally, there was there was the issue of emotional attachment, as he himself had experienced when representing India in Geneva, when 'he had felt with pride that the British Empire was in position of arbitrator in the League.' (Coudenhove-Kalergi, 1931c, p. 647). Like the Turkish intellectuals of this period, Ali saw Coudenhove in competition with more pragmatic politicians like Aristide Briand, who was willing to work within the existing framework of a League of Nations through such practical schemes as tariff negotiations (Coudenhove-Kalergi, 1931c, p. 648). ${ }^{30}$

Coudenhove implored his audience to help Europeans unite 'in the same way that France helped Italy to unite in the nineteenth century' (Coudenhove-Kalergi, 1931c, p. 644). His host at Chatham house was Leo Amery, the leading British Conservative who had served as Colonial Secretary under the previous government and later became Secretary of State for India. In 1939, Amery was serving on the boards on a number of private companies, and was active in anti-appeasement campaigns. What connected Amery to Coudenhove was likely his own masonic background, as well as his mother's Hungarian heritage, which had also paved the way for his deployment as an intelligence officer in the Balkans campaign during the First World War. However, he was also sceptical about the capacity to live with 'two patriotisms', one for Europe, and one for the British Empire.

By the late 1930s, the League of Nations had become an established forum for discussing pan-regional identities (more on this, see Richard, 2012). Meanwhile, Coudenhove's audience at Chatham House had become more narrowly confined to the vicissitudes of British national politics in the context of appeasement. ${ }^{31}$ Coudenhove argued that it was not only in Britain's strategic interest to 'become European', but that 'by the invention of the aeroplane England ceased to be an island from a strategic point of view' (Coudenhove-Kalergi, 1939, p. 623). Conversely, the new totalitarian states, Nazi Germany and the Soviet Union, were a threat not just to Europe but to the entire League of Nations. This changed the relationship between

30 On the Turkish reactions pitting Coudenhove as an alternative to Briand, see Capan and Onursal (2007).

31 The classic book of the time which captures this atmosphere was written under the pseudonym of Cato by a group of cross-bench authors, Michael Foot, Frank Owen and Peter Howard (1940). 
the two dramatically. Coudenhove also described his present as a kind of Cold War: 'Now we are facing the great problem whether or not Europe will emerge from the unbloody war in which we are living without having a bloody war.' (CoudenhoveKalergi, 1939, p. 627). Even if that war should happen, in the longer term, he hoped that Britain would be working not for its own interests but also 'for the liberty of the little States' of Eastern and Central Europe (Coudenhove-Kalergi, 1939, p. 631).

The list of attendees and their response to Coudenhove's ideas offer much material for exploring the immediate context of thinking about Europe's future, as Britain was struggling with questions of appeasement and strategic pro-communism. His discussants now consisted of largely English politicians with conservative views, an anti-appeasement stance, an interest in the Balkans and work in the Colonial Office. The only point of continuity with the meeting in 1931 was Leo Amery, who echoed Coudenhove's sentiments about the need for European unity, but was sceptical about the possibility. In his view, by contrast to the British Commonwealth with its 'historical unity' provided by 'a system of common ideals, of political liberty and of the reign of law', Europe had to rely on a much older fabric of ideals drawn from 'Greece, Rome and Palestine', which may be in the hearts of Europeans and yet was far from the minds at present. Rome and Palestine' (Coudenhove-Kalergi, 1939, p. 633). Other attendees included former Times editor and author of a book on the Habsburg Monarchy, Wickham Steed, the British military writer with a special interest in the Balkans, Vandeleur Robinson, and another colonial official, Sir Ronald Storrs. By contrast to the discussion in 1931 in the same context, when Coudenhove and his audience agreed that Britain could not be part of Pan-Europe, foregoing its special obligations to the Commonwealth, the atmosphere in 1939 had changed. The background for this change was Coudenhove's conception of Soviet and Nazi totalitarianism which he thought the alliance with Britain would help mitigate. The 1937 edition of this book pitted the British Union Jack against the Soviet hammer and sickle on its cover, with the profile of Athena representing Europe in its head (Coudenhove-Kalergi, 1937b).

Another dramatic change was Coudenhove's exile to New York and the replacement of Vienna with New York as the capital of Pan-European movement. After the annexation of Austria by Germany in 1938, when Coudenhove was forced to flee Austria, the movement's central idea to revive a European multi-ethnic empire with a base in Vienna had evidently failed. In 1940, the Coudenhoves left Europe for New York. Obtaining a teaching post in history and politics at New York University, supported by the Carnegie Foundation, Coudenhove revived Paneuropa in exile by founding a 'Research Centre for European reconstruction', which hosted a Paneuropean congress there in 1943, inviting other exiles from Europe. "It is our conviction that dismemberment of our continent or its partition into spheres 
of influence would inevitably lead, in a near future, to World War III. Fifteen exEuropeans in the U.S. last week raised this warning against Yalta, Dumbarton Oaks, the whole trend of Big Three power-thinking. Their alternative: a European confederation of independent states, linked by a continental Parliament, Cabinet, President and Army. Principal sponsor of last week's 'Declaration of European Interdependence' was Count Richard N. Coudenhove-Kalergi.' (Time Magazine, 1945). Coudenhove had been popularising his Paneuropean idea in the United States in the 1920s, too, at a time when visits by the European aristocracy were covered by the country's illustrated press. ${ }^{32}$ Indeed, the New York Times contains some of the most consistent international press coverage in the history of the movement. In the 1940s, his idea of Europe focused on the struggle against totalitarianism of the Nazi and Soviet variant, before becoming more oriented on democratic values as we would understand them today after the Second World War. Throughout this period, his community of followers was organised into national groups, even though there was a strong German influence since the movement's main journal Paneuropa, appeared mostly in German. The movement and its journal, Paneuropa, was as much a collection of proposals for the future as it was a receptacle for a variety of ideas and a mouthpiece for polling public opinions on all things European. Coudenhove's ideas, first nurtured on the ruins of the Habsburg empire, appeared utopian and idealistic and were often mocked and caricatured in the interwar period. In the heyday of Nazi propaganda, he attracted intense criticism for his utopianism regarding the question of race by key Nazi foreign policy ideologue Max Clauss, editor of the foreign language magazine Signal, who saw Coudenhove as a pawn in the hands of a Britishdominated Europe (Max, 1943). ${ }^{33}$ Paneuropa faded from view in European political discourse during Nazi Germany's rapid expansion in the Second World War, when Coudenhove himself went into exile to Switzerland and then to the United States.

The years of the war coincided with a far greater openness in Coudenhove's mind regarding the relationship between Europe's geographical frontiers and its political salvation from the menace of Nazism (Coudenhove-Kalergi, 1935). In this period, Coudenhove became more critical of democracy and in fact admitted the need to be pragmatic about the form of government in the face of greater threats such as totalitarianism (Coudenhove-Kalergi, 1936). But during Europe's second postwar, Coudenhove's plans appeared in a new light, as they came to be entangled with the practical project of European integration which was spearheaded by such politicians

32 Cf. Coudenhove's visit to Chicago covered in the LA Times: 'Seek United States of Europe: Advocates Plan Congress in Vienna', Los Angeles Times, 3 December 1925, 3.

33 The propaganda journal Signal, edited under the auspices of the Wehrmacht, appeared from 1940 to 1945 in more than fifteen languages, except German, with a circulation size of up to two million - most of it in France. See esp. 'Map of Europe's cultural and historical development', in Clauss (1944). See also Clauss, (1942) and Dollinger (1969). From Facsimile Querschnitte durch Zeitungen und Zeitschriften, 14 (Munich, Bern, Vienna: Scherz, 1969). On Signal in context, cf. Majer and Höhne (2014). 
as Robert Schuman and Jean Monnet, and regarded with benevolence by Winston Churchill. At this point, Coudenhove returned to his earlier conception whereby the emerging Soviet civilization was Europe's main enemy. The importance of joint colonial administration - central to his proposals in the 1920s - was now also carefully omitted, as were his ideas of a corporatist state which smacked rather too much of central and southern Europe's governments of the right from the interwar period.

\section{Into the Cold War: Anti-Sovietism as a Source of European Unity}

Immediately after the end of the war, Coudenhove returned to Europe, resuscitating his acquaintance with Leo Amery and with Winston Churchill, whose famed Zurich speech for a United States of Europe, given in 1946 to inspire a new union of Western European States, owed its ideological foundations to Coudenhove. As he put it, the work of Pan-European unification 'owes so much to Count Coudenhove-Kalergi'. Just like Coudenhove, who postulated the example of the union of Swiss cantons as an example for Europe, Churchill concluded his admonition for a need for Europe to unite by postulating that Europe should be 'as free and happy as Switzerland is today' (Churchill, 1950, p. $199 \mathrm{ff}$ ). At the same time, as far as his own nation was concerned, Churchill indicated that alongside this European Switzerland, there was still room for a British Empire which was associated but not integrated in the European Union of states. ${ }^{34}$ On top of these efforts, Coudenhove also mobilized his connections with Catholic dissident circles of anti-Nazi resistance, including Konrad Adenauer, with the desire to firmly promote a Paneuropean Union through a European party. By writing another retrospective on his own lifework, Coudenhove made sure that his name was not forgotten as new projects for European unity got under way (Coudenhove-Kalergi, 1949).

The economic experiences of the Paneuropean community were still useful in the interwar and wartime period, and Coudenhove had an impact on the design of the Marshall plan ${ }^{35}$ On the whole, Coudenhove's activities for European integration in the period after World War II were far less extensive and he refused to associate with most other European integration movements. The only organization he was formally involved with at this stage was the Centre for European Documentation and Information (CEDI). Located between the Dreyfusard intellectual elitists and the fascist neo-imperialists, and influenced by propaganda institutions such as the Comintern and the CIA which were founded between the mid-1930s and the 1940s, it was a centralised office for the propagation of European unity. Initiated by Otto von Habsburg, who, like Coudenhove, lived in exile in New York, it was also supported by

34 On Churchill's first discussion of Coudenhove's work, see Churchill (1930).

35 On Coudenhove-Kalergi as an inspiration for the European League for Economic Cooperation headed by Jacques Lacour-Gayet and Daniel Serruys, see Kunz (1948). 
General Franco of Spain. By the time of his death in 1972, Coudenhove's Paneuropa Union had been taken over by Otto von Habsburg, who merged it with CEDI. ${ }^{36}$

Increasingly, Coudenhove's vision of Europe's future depended on opposition to the Soviet Union more than any other political entity. Would the European Union have ever been viable without the Soviet Union? The political thought of Richard Coudenhove-Kalergi enables historians to engage with this question through a biographical lens. Modernity was a key to joining civilization; but a glorious past such as Europe could not be retrospectively manufactured. Thus Europe was the only continent which did not technically require the endorsement of modernity in order to count as civilised.

Coudenhove's ever-changing notion of Europe, which is expressed in the title of one of his brochures, 'Europe To-Morrow', reflects what Reinhart Koselleck has described as a special semantic of time in periods of political crises (Koselleck, 2006). His Europeanism allowed to reinvigorate Europe's capacity for political hegemony in the age of imperial decline. This semantic was the product of a political moment that was symbolically associated with the Bolshevik revolution of 1917 - but in reality, percolated throughout western Europe as well as Asia Minor through numerous other types of revolution and radical transformation, including Mustafa Kemal's shaping of modern Turkey. His case also foregrounds the role of German intellectuals within the cultural construction of the West, which is otherwise more prominently associated with transatlantic discourses such as Winston Churchill's Fulton Speech.

Coudenhove's status as the prophet of a political movement which crossed party political and national boundaries could be usefully compared with the cross-party and parapolitical movements which are currently emerging in Europe and in the transatlantic world on the left and the right. ${ }^{37}$ Coudenhove's idea of establishing a dedicated news outlet - the Paneuropa Verlag - which would allow him to defend his conception of Europe's future in an 'unbloody war' could be used to put twenty-first century efforts to renew the media landscape in historical perspective. His emphasis on surveys and questionnaires, which he used not only to gauge opinions but primarily to disseminate his own ideas, echoed the political uses of plebiscites and referenda in a volatile Europe of his day. Now, as new forms of mass political mobilisation have shifted European frontiers once again in places like Crimea, it is instructive to revisit the work of this one-man propagandist as a small case study of soft power. His example allows for a better understanding of the social and intellectual mechanisms by which ideologies of soft power evolved between the age of empire and the age of the Cold War, before becoming appropriated by other political movements which

36 On this period of Coudenhove's influence, see Conze, Abendland und Westeuropa, $76 \mathrm{ff}$.

37 For a good analysis, see, for instance, Plattner (2010) and Eichengreen (2017). 
were either more violent, like Nazi conceptions of Europe, or more forceful, like Europe's post-World War II integration. A mixture of idealistic liberalism and political opportunism, Coudenhove's changing notion of European civilization shows that the cultural Iron Curtain could also be seen as one of the long-term effects of Europe's postimperial succession crisis. ${ }^{38}$ Understanding the intellectual impact of imperial decline in the long-term might also help current analyses of the new populism in the 'West', as well as the anti-European 'pan-movements' of the age of globalisation. ${ }^{39}$

\section{References}

Amery, L. (1930). The British Empire and the pan-European idea. Journal of the Royal Institute of International Affairs, 9(1), 1-22.

Ashworth, L. M. (2002). Did the realist-idealist great debate ever happen? A revisionist history of international relations. International Relations, 16(1), 33-51. https://doi.org/10.1177/0047117802016001004

Auerbach, B. (1898). Les races et les nationalités en Autriche-Hongrie. Paris: Alcan.

Aydin, C. (2007). The politics of Anti-Westernism in Asia: Visions of world order in Pan-Islamic and Pan-Asian thought. New York Chichester, West Sussex: Columbia University Press.

Bachmann, S. D., \& Gunneriusson, H. (2015). Russia's hybrid warfare in the East: The integral nature of the information sphere. Georgetown Journal of International Affairs, 16. Retrieved from https://ssrn.com/abstract=2670527

Bacik, G. (2011). Turkey today: Emerging ideological scenario. Policy Perspectives, 8(1), 21-36.

Barlas, B., \& Güven, S. (2009). Turkey and the idea of regional integration in Europe: The interwar experience, 1923-1939. Middle Eastern Studies, 45(3), 425-446.

Barlas, D., \& Güvenc, S. (2009). Turkey and the idea of regional integration in Europe: The interwar experience, 1923-1939. Middle Eastern Studies, 45(3), 425-446.

Bassin, M. (2004). Horizons géographiques. Rosny-sous-Bois: Bréal.

Bayly, C. A., \& Eugenio F. B. (Eds.) (2008). Giuseppe Mazzini and the globalisation of democratic nationalism 1830-1920 (Proceedings of the British Academy 152). Oxford \& New York: Oxford University Press for The British Academy.

Bedri, T. (1934). Die Wirtschaftliche Erneuerung Der Türkei. Paneuropa, 115-117.

Bluntschli, J. C. (1886). Allgemeine Staatslehre. Stuttgart: Cotta.

Bock, H. (Eds.) (1994). Entre Locarno et Vichy: Les relations culturelles franco-allemandes dans les années 1930, 1, 25-61.

Boelcke, W. A., \& Dollinger, H. (Eds.) (1969). Facsimile Querschnitte durch Zeitungen und Zeitschriften (14). Munich, Bern, Vienna: Scherz.

Boli, J., \& Thomas, G. (Eds.) (1999). Constructing world culture: International nongovernmental organizations since 1875. Stanford: Stanford University Press.

38 Even before Paneuropa, Coudenhove discussed the future of Vienna in postimperial Europe (CoudenhoveKalergi, 1920).

39 On modern day populism and their emotional contagion, Freeden (2017). On new pan-movements, see Aydin (2007). 
Breuer, S. (1999). Grundpositionen der deutschen Rechten 1871-1945. Tübingen: Discord.

Breuer, S. (2001). Ordnungen der Ungleichheit. Die deutsche Rechte im Widerstreit ihrer Ideen 1871-1945. Darmstadt: Wissenschaftliche Buchgesellschaft.

Brockhausen, K. (1924). Europa 1914 und 1924. Bild und Gegenbild. Vienna: Wiener literarische Anstalt.

Bühler, K. (1929). Europa und der amerikanische Kulturwille. Europaeishe Revue, 5, 635-650.

Burgard, O. (2000). Das gemeinsame Europa--von der politischen Utopie zum aussenpolitischen Programm: Meinungsaustausch und Zusammenarbeit pro-europäischer Verbände in Deutschland und Frankreich, 1924-1933. Frankfurt am Main: Verlag Neue Wissenschaft.

Call, A. D. (1927). Review of Pan-Europe by Richard N. Coudenhove-Kalergi, The American Journal of International Law, 21(2), 384-385.

Capan, Z. G., \& Onursal, O. (2007). Situating Turkey within the European Union. Perspectives on European Politics and Society, 8(1), 98-108.

Chamberlain, H. S. (1899). Die Grundlagen des 19. Jahrhunderts (Vol I). Munich: Bruckmann.

Churchill, W. (1939). Wir Engländer und Paneuropa. Paneuropa, 3, 77-81.

Churchill, W. (1950). Europe Unite. Speeches 1947 and 1948. London: Cassell.

Clauss, M. (1943). Tatsache Europa. Amsterdam: Volk und Reich.

Clauss, M. (1969). Irrweg Paneuropa. Paneuropa Erronea, In H. Dollinger (Ed.), Facsimile Querschnitt durch Signal (p. 44f). München u. a.

Clauss, M. (Ed.) (1944). Map of Europe's cultural and historical development. Signal, 11.

Conrad, B. (2015). Volksabstimmungen Als Ultima Ratio? Die Plebiszite an Polens Grenzen Nach Dem Ende Des Ersten Weltkriegs', Zeitschrift Für Ostmitteleuropa-Forschung, 64(2), 174-193.

Conze, V. (2004). Richard Codenhove-Kalergi: Umstrittener Visionär Europas. Gleichen: MusterSchmidt.

Conze, V. (2005). Das Europa der Deutschen. Ideen von Europa in Deutschland zwischen Reichstradition und Westorientierung (1920 - 1970). Oldenbourg: Institut für Zeitgeschichte.

Corre, A. (1894). L'ethnographie criminelle. Paris: Reinwald.

Coudenhove to Louis Loucheur, 3 February 1928, 3 May 1928, telegram of 10 December 1928, and 19 January 1929, in Stanford, Hoover Institution Archives (HA), Loucheur Papers.

Coudenhove-Kalergi to Reichskanzler, in BA, R 43 I/125, pp. 364-377

Coudenhove-Kalergi to the Reichskanzler. Paris, 27 March 1931, in BA R 43 I/125, pp. 265-266.

Coudenhove-Kalergi, R. (1920). Wien als Welthauptstadt. Die Zukunft, 16, 61-64.

Coudenhove-Kalergi, R. (1922). Paneuropa. Ein Vorschlag. Neue Freie Presse, 3-4. Retrieved from http://anno.onb.ac.at/cgi-content/anno?apm=0\&aid=nfp\&datum=19221117\&zoom=2

Coudenhove-Kalergi, R. (1923a). An die europäische Jugend. Paneuropa, 11-12, 1.

Coudenhove-Kalergi, R. (1923b). Pan-Europa. Vienna \& Leipzig: Pan-Europa-Verlag.

Coudenhove-Kalergi, R. (1924a). Das Pan-Europa-Programm. Paneuropa, $2,4$.

Coudenhove-Kalergi, R. (1924b). Paneuropa, 33.

Coudenhove-Kalergi, R. (1924c). Paneuropa. Leipzig \& Vienna: Paneuropa.

Coudenhove-Kalergi, R. (1925a). Adel-Technik-Pazifismus. Paneuropa-Verlag: Wien Leipzig. 
Coudenhove-Kalergi, R. (1925b). Antworten auf eine Rundfrage I. Paneuropa, 1(3), 55-62.

Coudenhove-Kalergi, R. (Ed.) (1930). Nietzsche als Paneuropäer (excerpts from Nietzsche). Paneuropa, 3, 95-101.

Coudenhove-Kalergi, R. (1931a). Die Türkei und Wir. Paneuropa I. 13-14.

Coudenhove-Kalergi, R. (1931b). Paneuropa ABC (pp. 24-25). Leipzig, Vienna: Paneuropa.

Coudenhove-Kalergi, R. (1931c). The Pan-European outlook. International Affairs (Royal Institute of International Affairs 1931-1939), 10(5), 638-651.

Coudenhove-Kalergi, R. (1935). Wo liegt die Ostgrenze Europas? Paneuropa I, 318-322.

Coudenhove-Kalergi, R. (1936). Krise der Demokratie? Paneuropa I, 216-222.

Coudenhove-Kalergi, R. (1937a). Der Balkan Als Vorbild. Paneuropa, 122.

Coudenhove-Kalergi, R. (1937b). Totaler Staat, Totaler Mensch Glarus: Paneuropa-Verlag.

Coudenhove-Kalergi, R. (1938). Europas Grenzen. Paneuropa I, 40-46.

Coudenhove-Kalergi, R. (1939). Europe To-Morrow. International Affairs, 18(5), 623-640. https://doi.org/10.2307/3019776

Coudenhove-Kalergi, R. (1949). Der Kampf um Europa. Aus meinem Leben. Zurich: Paneuropa.

Coudenhove-Kalergi, R. (1966a). Ein Leben für Europa. Meine Lebenserinnerungen (p. 21). Berlin, Cologne: Kiepenheuer\&Witsch.

Coudenhove-Kalergi, R. (1966b). Ein Leben für Europa. Meine Lebenserinnerungen (pp. 223224). Berlin, Cologne: Kiepenheuer\&Witsch.

Coudenhove-Kalergi, R. (1971). Weltmacht Europa. Stuttgart: Seefeld.

Dawson, C. (1932). The modern dilemma: The problem of European Unity. London: Sheed \& Ward.

Dawson, C. (1934). The making of Europe: An introduction to the history of European Unity. Paris: Editions Spes.

De Lanux, P. (1929). Überwindung des Atlantik. Europäische Revue, 5(2), 607-613.

Delaisi, F. (1929). Les Deux Europes. Paris: Payot.

Delanty, G. (1995). Inventing Europe: Idea, identity, reality. London: Macmillan.

Die nationale Staatenbildung und der moderne deutsche Staat. (1881). Berlin: Habel.

Eichengreen, B. (2017). The populist turn in American politics. Current History, 1(116), 24-30.

Erdman, K. D. \& Koops, T. (Eds.) (1982). Die Kabinette Brüning I u. II. In Akten der Reichskanzlei. Weimarer Republik (V. 2, pp. 1000-1001). Boppard am Rhein: Harald Boldt.

Febvre, L. (1999). L'Europe. Genèse d'une civilisation. Cours professé au Collège de France en 1944-1945. Paris: Perrin, 1999.

Fénelon, F. (1720). Sentiments on the Balance of Europe. Two Essays on the Balance of Europe. London.

Fisher, H. A. L. (1938). History of Europe (3 vols.). London: Edward Arnold.

Foot, M. (1940). Frank Owen and Peter Howard: Guilty men. London: V. Gollancz.

Fourgeaud, A. (1929). „Die syndikale Republik“, Europäische Revue, IV(12).

Freeden, M. (1998). Ideologies and political theory: A conceptual approach. Oxford: Oxford University Press.

Freeden, M. (2017). After the Brexit referendum: Revisiting populism as an ideology. Journal of 
Political Ideologies, 22(1), 1-11.

Gehler, M. (2002). Der Lange Weg nach Europa. Innsbruck: StudienVerlag.

Greiner, G. (2015). Europäisiert und Modern: Wahrnehmungen Der "Neuen Türkei" in EuropaBewegungen Der Zwischenkriegszeit. Themenportal Europäische Geschichte. Retrieved from https://www.europa.clio-online.de/essay/id/artikel-3792

Gumplowicz, L. (1879). Das Recht der Nationalitäten und Sprachen in Österreich-Ungarn. Innsbruck: Wagner.

Gusejnova, D. (2013). Adel als Berufung. Adlige Schriftsteller im deutschsprachigen Europadiskurs, 1919-1925. In E. Conze, W. Meteling, J. Schuster \& J. Strobel (Eds.). Aristokratismus und Moderne. Adel als politisches und Kulturelles Konzept, 1890-1945 (pp. 252-281). Cologne, Weimar, Vienna: Böhlau.

Gusejnova, D. (2016). European Elites and ideas of Empire, 1917-57. Cambridge: Cambridge University Press.

Halfeld, A. (1928). Das amerikanische Wirtschaftsproblem und Europa. Europäische Revue, 4(1), 391-397.

Hansen, P. \& Jonsson, S. (2014). Eurafrica: The untold history of European integration and colonialism. London: Bloomsbury Publishing.

Heffernan, M. J. (1998). Meaning of Europe: Geography and geopolitics. London \& New York: Oxford University Press.

Hugo, V. (1849). United States of Europe. Paris Peace Congress.

Judson, P. (2016). The Habsburg Empire: A new history. Cambridge, Mass \& London: The Belknap Press of Harvard University Press.

Kajima, M. (1971). Coudenhove-Kalergi; Le Pionnier de l'Europe unie. Lausanne: Centre de recherches européennes.

Kjellén, R. (1917). Studien zur Weltkrise. Munich: H. Bruckmann.

Kjellén, R., Haushofer, K., Hassinger, H., Maull, O., \& Obst, E. (1930). Die Grossmächte vor und nach dem Weltkriege. Leipzig und Berlin: B.G. Teubner.

Koselleck, R. (2006). Crisis. Journal of the History of Ideas, 67(2), 357-400.

Kunz, J. L. (1948). Pan Europe, The Marshall Plan countries and the Western European Union. The American Journal of International Law, 42(4), 868-877.

La Rochelle, P. D. (1931). L'Europe contre les patries. Paris: Stock.

Lipgens, W. (1982). A history of European integration 1945-1947: The formation of the European Unity movement. Oxford: Clarendon Press.

Los Angeles Times. (December, 3, 1925). Seek United States of Europe: Advocates Plan Congress in Vienna.

Majer, M. \& Höhne, W. (2014). Europäische Einigungsbestrebungen vom Mittelalter bis zur Gründung der Europäischen Wirtschaftsgemeinschaft (EWG) 1957 (Juris fontes 3). Karlsruhe, Baden: KIT Scientific Publishing.

Marrus, M. (1985). The unwanted: European refugees in the twentieth century. New York: Oxford University Press.

Maximos, D. (1934). Griechisch-Türkische Freundschaft. Paneuropa, 111-112.

Müller, G. (2005). Europäische Gesellschaftsbeziehungen nach dem Ersten Weltkrieg das Deutsch- 
Französische Studienkomitee und der Europäische Kulturbund. Munich: Oldenbourg.

Müller, M. (1999). In cerca dell'Europa: realtà e rappresentazioni di un continente. Contemporanea, $1,81-87$.

New York Times. (December 22, 1942). European Union is favored. count Coudenhove-Kalergi replies to some objections to his plan.

Nietzsche, F. (2002). Beyond Good and Evil: Prelude to a Philosophy of the Future (R.-P. Hostmann \& J. Norman, Eds.). Cambridge: Cambridge University Press.

Papadaki, M. (2012). The "Government Intellectuals": Nicolas Politis - An intellectual portrait. The European Journal of International Law, 23(1), 221-231.

Parmar, I. (2002). Anglo-American elites in the interwar years: Idealism and power in the intellectual roots of Chatham House and the Council on foreign relations. International Relations, 16(1), $53-75$.

Paul, I. U. (2003). Konservative Milieus und die Europäische Revue (1925 - 1944). In M. Grunewald, U. Puschner, \& H. M. Bock (Eds.), Le milieu intellectuel conservateur en Allemagne, sa presse et ses réseaux (1890-1960). Bern: P. Lang.

Plattner, M. (2010). Populism, pluralism, and liberal democracy. Journal of Democracy, 21(1), 81-92.

Politis, J. (1946). L'avenir de l'Europe. Baconnière.

Popovici, A. (1906). Die Vereinigten Staaten von Groß-Österreich. Politische Studien zur Lösung der nationalen Fragen und staatrechtlichen Krisen in Österreich-Ungarn. Leipzig: B. Elisch,

Popovici, A. (1918). La Question Rumaine en Transylvanie et en Hongrie. Lausanne \& Paris: Payot.

Porter, B. (2002). Lord Davies, E.H. Carr and the spirit ironic: A comedy of errors. International Relations, 16(1), 77-97.

Pugh, M. (2002). Policing the world: Lord Davies and the quest for order in the 1930s. International Relations, 16(1), 97-115. https://doi.org/10.1177/0047117802016001007

Qvortrup, M. (2015). A brief history of self-determination referendums before 1920. Ethnopolitics, 14(5), 547-554.

Reytier, M.-E. (2004). Die Fürsten zu Löwenstein an der Spitze der deutschen Katholikentage. Aufstieg und Untergang einer Dynastie (1868-1968). In G. Schulz \& M. Denzel (Eds.). Deutscher Adel im 19. und 20. Jahrhundert, Büdinger Forschungen zur Sozialgeschichte 2002 und 2003. St. Katharinen: Scripta Mercaturae.

Rich, P. (2002). Reinventing peace: David Davies, Alfred Zimmern and liberal internationalism in interwar Britain. International Relations, 16(1), 117-133. 10.1177/0047117802016001008

Richard, A.-I. (2012). Competition and complementarity: Civil society networks and the question of decentralizing the league of nations. Journal of Global History, 7(2), 233-256.

Richard, A.-I. (2014). In search of a suitable Europe: Paneuropa and the Netherlands in the interwar period. In C. Reijnen \& M. Rensen (Eds.). European studies: An interdisciplinary series in European culture, history and politics (pp. 247-269). Amsterdam: Amsterdam University Press.

Roland, I. (1933). Wiederauftreten Ida Rolands in Wien. Neue Freie Presse.

Saint-Pierre, A. (1714). A project for settling an everlasting peace in Europe. First proposed by Henry IV of France, and approved by Queen Elizabeth, and most of the then Princes of Europe, and now discussed at large, and made particable by the Abbot St. Pierre, of the French Academy. London: J. Watts. 
Schmitt, C. (1929). Die europäische Kultur im Zwischenstadium der Neutralisierung. Europäische Revue, viii, 517-530.

Seed, H. W. (1928). Pax Americana. Europäische Revue, 4(1), 100-107.

Shevtsova, L. (2015). Forward to the Past in Russia. Journal of Democracy, 26(2), 22-36.

Shore, C. (2000). Building Europe. The cultural policies of European integration. London: Routledge.

Sismondi, J. C. L. (1839). Etudes sur les Constitutions des peuples libres. Bruxelles: Société Typographique Belge.

Spencer, H. (1904). The Spectator (No. 3943).

Stråth, B. (Ed.) (2010). Europe and the Other and Europe as the Other (4. Print, Series Multiple Europes 10). Bruxelles: Lang.

The Pan-European Outlook. (1931, September). International Affairs (Royal Institute of International Affairs 1931-1939), 10(5), 638-651.

Thorsten, B.-B. (2007). European Transfigurations-Eurafrica and Eurasia: Coudenhove and Trubetzkoy revisited. The European Legacy, 12(5), 565-575.

Time Magazine. (1945, March 26). One Europe.

Toynbee, A. (1931). Historical parallels to current international problems. International Affairs (Royal Institute of International Affairs 1931-1939), 10(4), 477-492.

Wehberg, H. (1927). Das Recht auf den Namen Paneuropa. Friedenswarte, 102-103.

Woolf, S. (2003). Europe and its historians. Contemporary European History, 12(3), 323-337.

Wright, C. (1927). Pan-Europe, Richard N. Coudenhove-Kalergi. Political Science Quarterly, 42(4), 633-636.

Ziegerhofer-Prettenthaler, A. (2004). Botschafter Europas: Richard Nikolaus Coudenhove-Kalergi und die Paneuropa-Bewegung in den zwanziger und reissiger Jahren. Vienna: Böhlau. 
